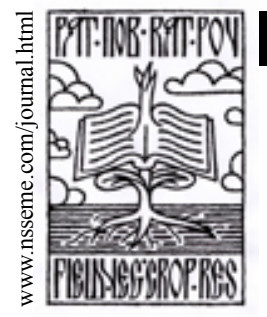

\title{
Effect of Biostimulators on Sunflower Germination Energy and Seed Germination
}

\author{
Zlatica Miladinov • Velimir Radić • Vladimir Miklič • Jovan Crnobarac • \\ Igor Balalić • Milan Jocković • Jelena Mrđa
}

\author{
received: 6 March 2014, accepted: 26 May 2014 \\ published online: 18 June 2014 \\ (c) 2014 IFVC \\ doi: $10.5937 /$ ratpov51-5625
}

\begin{abstract}
Summary: The aim of this paper was to examine the effect of biostmulators on seed quality parameters - germination energy and germination, depending on the genotype and age of sunflower seeds. Testing has been conducted at the Institute of Field and Vegetable Crops on four cytoplasmic male sterile lines: OCMS-98 (L1), HA-NS-26 (L2), PH-BC2-74 (L3) and VL-A-8 (L4). Seed was produced in the period from 2010 to 2012. Two seed variants were tested - treated with metalaxyl-m and non-treated. Prior to sowing, seed was treated with fertilizes Slavol S, Bioplant Flora, and their combination. Selecting the right biostimulator for a particular genotype may lead to increased germination energy and germination, which has the positive effect on the number of plants per unit area, and hence the yield.

Keywords: biostimulators, energy, germination, seeds, seed age, sunflower
\end{abstract}

\section{Introduction}

Sunflower belongs to a group of the most significant annual crops which are grown for oil production (Šimić et al. 2008). It is grown on about 25 million acres worldwide (FAO 2012). One of the basic conditions for achieving high yields is sowing quality seed (Milošević et al. 1996). Germination and germination energy represent the most important indicators of seed quality (Poštić et al. 2010). In field conditions these indicators determine the number of plants per unit area - one of the three basic yield components (Crnobarac 1992). With reduction of seed vitality, the number of plants per unit area is also reduced, which negatively affects the yield (TeKrony \& Egli 1991). The quality of seed is affected by numerous factors: weather conditions and quality of combine harvest, terms of manipulation of mown seed - from harvester

Z. Miladinov* • V. Radić • V. Miklič • I. Balalić • M. Jocković • J. Mrđa Institute of Field and Vegetable Crops, M. Gorkog 30, 21000 Novi Sad, Serbia

e-mail: zlatica.miladinov@nsseme.com

\section{J Crnobarac}

University of Novi Sad, Faculty of Agriculture, Trg D. Obradovića 8, 21000 Novi Sad, Serbia to the processing centre, storage conditions of natural and processed seed, time and method of seed processing, etc (Nenadić et al. 2011). Areas under sunflower in Serbia vary from year to year, depending on the yield achieved in previous year, but also on economic situation and prices of this important oil crop (Miklič et al. 2004). Therefore, it often happens that the seed produced in one year is not used for sowing in the next following season but is rather 2 to 3 years later (Mrda 2010).

There is not much information in literature on biostimulators effect on seed germination energy GE and total germination TG, depending on seed age. Positive effect of biostimulators on old seed quality indicators was proven on an example of a maze and soy (Vinković et al. 2007), as well as on some vegetables: celery, parsley, green salad and leek (Yildirim et al.2007). Biostimulators are substances that enhance the immune system of cultivated plants and provide support for plant metabolism. Their use helps reduce the amount of chemicals

\section{Acknowledgements:}

This study is a part of the project TR31025 funded by the Serbian Ministry of Education, Science and Technological Development. 
used in agriculture (Kolomazik et al. 2012). The use of biostimulators (plant hormones, vitamins, etc.) stimulates seed germination, especially the one under stressful conditions (Zaborsky et al. 2002). Biostimulators can be applied at different stages of plant growth and development, depending on the type of biostimulators (Tkalec 2010). Those that are based on the tryptophan and proline amino acids may be used for reducing the effects of environmental stress (Vinković et al. 2007). In order to perform the desired effect, biostimulators must be able to penetrate into the plant tissue. This is of great importance, especially in field conditions where treated plants are exposed to different weather conditions (Kolomazik et al. 2012). Many bacteria acting as biostimulators can synthesize physiologically active substances such as gibberellins, cytokinins, and vitamins, and thereby stimulate microbial activity and better plant growth and development (Govedarica 2002).

Production of sunflower parent lines is very specific - primarily due to spatial isolation which needs to be at least $3 \mathrm{~km}$. Due to organization of line production, it cannot be sowed each year, but after two or three years. During that period, value of seed quality parameters declines.

The aim of this study was to investigate the effect of biostimulators on parameters of seed quality - germination energy and germination, depending on the genotype and seed age.

\section{Materials and Methods}

The study was carried out at the Institute of Field and Vegetable Crops in Novi Sad in October 2013. Testing was conducted on sunflower seed of four cytoplasmic male sterile lines - OCMS98 (L1), HA-NS-26 (L2), PH-BC2-74 (L3) and VL-A-8 (L4), produced in the period from 2010 to 2012, meaning that the tested seed was one, two, and three years old. Germination (TG total germination) and seed germination energy (GE) were tested by standard laboratory methods under conditions which imply 4x100 seeds at $25^{\circ} \mathrm{C}$ and $95 \%$ humidity with four days of incubation for GE and 10 days of seed TG (ISTA 2009). Filter paper rolls and sterile sand were used as a substrate. Two seed variants were used for research: treated (with a.m. metalaxyl-m) and non-treated seed.

Both seed variants were treated with the following commercial preparations biostimulators:

1. Slavol S (a.m. indol-3-acetic acid), in concentration of $25 \%(S)$,
2. Bioplant Flora (a.m. humus extract, humic acid, fulvic acid, amino acid, phytohormones, macro and micro elements in chelating form, $\mathrm{N}, \mathrm{K}_{2} \mathrm{O}$ ), in concentration of $2 \%$ (B),

3. Slavol $S+$ Bioplant Flora in the above mentioned concentrations $(S+B)$,

4. Control variant - seed not treated with biostimulators $(\mathrm{K})$.

The data were statistically processed by analysis of variance of three-factorial split-splitplot experimental design (A-genotype, G-seed production year, C-biostimulators) by using software package Statistica 8. Significance of obtained differences between treatments was determined by LSD (Least Significant Difference) test, at significance thresholds of $5 \%$ and $1 \%$ (Hadživuković 1991).

\section{Results and Discussion}

\section{Seed germination energy - filter paper as a substrate}

Analysing the obtained results it can be determined that OCMS-98 line, at both seed variants, had better average GE in relation to other lines - $95 \%$ and $95 \%$, while in both cases, the seed produced in 2011 and 2012 had significantly better average value of this seed quality indicator in relation to seed from 2010. On average, seed produced in 2012 had the best GE - 97\% (at non-treated seed) and $96 \%$ (seed treated with metalaxyl), as shown in Table 1.

Observing the effect of biostimulators on seed $\mathrm{GE}$, it can be determined that treating seed with fertilizer Slavol S significantly influences GE on average for all lines, it increased GE for 5\% at non-treated variant, i.e. $5 \%$ at variant treated with metalaxyl. Significant improvement was also achieved by applying Bioplant Flora (B) $2 \%$ i.e. $2 \%$, but also with the combination of these two fertilizers $(S+B)-2 \%$ i.e. $3 \%$ in relation to control (K) variant. Earlier, Fries (1951) determined positive effect of biostimulators and amino acids arginine and asparagine on growth and development of lateral roots, as well as on forming of cotyledons on young pea plants.

Analyzing how parent lines seed reacts to application of biostimulators, it can be concluded that all fertilizers significantly increased GE at OCMS-98 line, where combination $S+B$ the improved GE by $6 \%$ with respect to non-treated seed, i.e. by $6 \%$ with respect to seed treated with metalaxyl-m. On average, Bioplant Flora increased GE by $6 \%$, i.e. $4 \%$, while Slavol $S$ 
Table 1. Effect of biostimulators on GE on a filter paper substrate

\begin{tabular}{|c|c|c|c|c|c|c|c|c|c|c|c|c|c|}
\hline \multirow{3}{*}{$\begin{array}{c}\text { Lines } \\
\text { A }\end{array}$} & \multirow{3}{*}{$\begin{array}{c}\text { Years } \\
\text { G }\end{array}$} & \multicolumn{6}{|c|}{ Seed non-treated } & \multicolumn{6}{|c|}{ Seed treated with metalaxyl } \\
\hline & & & iosti & ators ( & & Aver. & Aver. & & iosti & ators & & Aver. & Aver. \\
\hline & & $S$ & B & $S+B$ & $\bar{K}$ & $A^{*} G$ & $\mathrm{~A}$ & $S$ & B & $S+B$ & $\bar{K}$ & $A^{*} G$ & A \\
\hline \multirow{4}{*}{ L1 } & 2010 & 92 & 95 & 96 & 87 & 93 & \multirow{4}{*}{95} & 94 & 92 & 97 & 88 & \multirow{4}{*}{$\begin{array}{l}93 \\
95 \\
97\end{array}$} & \multirow{4}{*}{95} \\
\hline & 2011 & 97 & 98 & 97 & 91 & 96 & & 97 & 96 & 97 & 89 & & \\
\hline & 2012 & 98 & 98 & 98 & 94 & 97 & & 98 & 96 & 97 & 95 & & \\
\hline & $\mathrm{A}^{*} \mathrm{C}$ & 96 & 97 & 97 & 91 & & & 96 & 95 & 97 & 91 & & \\
\hline \multirow{4}{*}{$\mathrm{L} 2$} & 2010 & 85 & 79 & 72 & 81 & 79 & \multirow{4}{*}{90} & 83 & 81 & 70 & 79 & \multirow{4}{*}{$\begin{array}{l}78 \\
92 \\
96\end{array}$} & \multirow{4}{*}{89} \\
\hline & 2011 & 96 & 95 & 90 & 94 & 94 & & 95 & 90 & 91 & 91 & & \\
\hline & 2012 & 99 & 99 & 97 & 95 & 98 & & 97 & 95 & 96 & 94 & & \\
\hline & $\mathrm{A}^{*} \mathrm{C}$ & 93 & 91 & 86 & 90 & & & 92 & 89 & 86 & 88 & & \\
\hline \multirow{4}{*}{ L3 } & 2010 & 85 & 84 & 77 & 75 & 80 & \multirow{4}{*}{90} & 82 & 83 & 77 & 73 & \multirow{4}{*}{$\begin{array}{l}79 \\
94 \\
96\end{array}$} & \multirow{4}{*}{90} \\
\hline & 2011 & 97 & 92 & 95 & 93 & 94 & & 97 & 90 & 94 & 94 & & \\
\hline & 2012 & 97 & 96 & 100 & 95 & 97 & & 98 & 94 & 97 & 94 & & \\
\hline & $\mathrm{A}^{*} \mathrm{C}$ & 93 & 91 & 91 & 88 & & & 92 & 89 & 89 & 87 & & \\
\hline \multirow{4}{*}{ L4 } & 2010 & 85 & 79 & 82 & 77 & 81 & \multirow{4}{*}{90} & 82 & 77 & 80 & 77 & \multirow{4}{*}{$\begin{array}{l}79 \\
92 \\
96\end{array}$} & \multirow{4}{*}{89} \\
\hline & 2011 & 96 & 91 & 94 & 89 & 93 & & 97 & 88 & 92 & 89 & & \\
\hline & 2012 & 98 & 92 & 97 & 94 & 95 & & 96 & 95 & 97 & 95 & & \\
\hline & $\mathrm{A}^{*} \mathrm{C}$ & 93 & 87 & 91 & 87 & & & 92 & 87 & 90 & 87 & & \\
\hline \multirow{3}{*}{$\begin{array}{l}\text { Aver. } \\
\mathrm{G}^{*} \mathrm{C}\end{array}$} & 2010 & 87 & 84 & 82 & 80 & Pros. & 83 & 85 & 83 & 81 & 79 & \multirow{3}{*}{$\begin{array}{c}\text { Pros. } \\
\text { Aver. } \\
\text { G }\end{array}$} & 82 \\
\hline & 2011 & 97 & 94 & 94 & 92 & Aver. & 94 & 97 & 91 & 94 & 91 & & 93 \\
\hline & 2012 & 98 & 96 & 98 & 95 & G & 97 & 97 & 95 & 97 & 95 & & 96 \\
\hline \multicolumn{2}{|c|}{ Average $\mathrm{C}$} & 94 & 91 & 91 & 89 & \multicolumn{2}{|c|}{ Avera } & 93 & 90 & 91 & 88 & & \\
\hline
\end{tabular}

LSD

\begin{tabular}{|c|c|c|c|c|c|c|c|c|c|c|c|c|c|c|}
\hline \multirow[b]{2}{*}{ LSD } & \multicolumn{7}{|c|}{ Seed non-reated with metalaxyl } & \multicolumn{7}{|c|}{ Seed treated with metalaxyl } \\
\hline & $\overline{\mathrm{A}}$ & $\bar{G}$ & $\mathrm{C}$ & $\mathrm{A}^{*} \mathrm{G}$ & $\mathrm{A}^{*} \mathrm{C}$ & $\mathrm{G}^{*} \mathrm{C}$ & $\mathrm{A}^{*} \mathrm{G}^{*} \mathrm{C}$ & A & $\overline{\mathrm{G}}$ & $\bar{C}$ & $A^{*} G$ & $\mathrm{~A}^{*} \mathrm{C}$ & $\mathrm{G}^{*} \mathrm{C}$ & 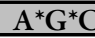 \\
\hline 05 & 3.68 & 9.75 & 3.31 & 1.26 & 0.70 & 1.22 & & 3.91 & 9.99 & 3.22 & 1.29 & 0.66 & 1.20 & \\
\hline & 7 & 7.05 & 5.1 & 1.77 & 96 & 171 & 30.3 & 6.10 & 1746 & 5.02 & 1.80 & 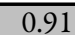 & 1.68 & 77 \\
\hline
\end{tabular}

increases it by $5 \%$, i.e. $5 \%$ (Table 1 ). Results are in accordance with Thi Lua \& Böhme (2001) who emphasised that biostimulators which contain amino acids and humic acids had positive effect on seed TG. Slavol S achieved the best average effect on GE in sunflower line L2 (HA-NS26). By treating seed with this biostimulator prior to sowing, value significantly increased by an average of $3 \%$, i.e. $4 \%$, while treating both variants with Bioplant Flora achieved increase of TG by $1 \%$. Mutual influence of these two fertilizers $(S+B)$ lead to negative effect and significant reduction of GE value by $4 \%$, i.e. $2 \%$ with relation to control variant (Table 1). Line L3 (PH-BC2-74) showed that fertilizers had significant effect on increasing GE with relation to seed that was not treated with biostimulators. On a three-year average, Slavol $S$ increased GE by $5 \%$, i.e. $5 \%$, Bioplant Flora - by $3 \%$, i.e. $2 \%$, and the combination of the two fertilizers increased GE by $3 \%$, i.e. $2 \%$, on average. By analyzing L4 (VL-A-8) sunflower line, it can be determined that Slavol $S$ achieved the best result and significantly improved seed GE by an average of 6\%, i.e. 5\%. Bioplant Flora did not have significant effect, while by mutual influence $(S+B)$, the value of this seed quality parameter significantly increased -by $4 \%$, i.e. $3 \%$, on a three-year average, in relation to control variant.

By observing the influence of biostimulators on TG, depending on the seed age, it can be concluded that all treatments had positive effect. Significant increase of TG was achieved by applying Slavol S. Treating the seed with this preparation led to the greatest efficiency with the three-year-old seed, by an average of $7 \%$, i.e., $6 \%$, respectively. Reducing the age of the seed reduces the influence of the preparation, thus the average value of TG with two-year-old seed was improved by $5 \%$, i.e., $6 \%$, while the lowest efficiency of this preparation was observed with one-year-old seed - by an average of $3 \%$, i.e., 2\%. Bioplant Flora biostimulator achieved the best influence on the three-year-old seed by increasing the TG by an average of $4 \%$ with both variants. This preparation achieved significant influence on two-year-old seed where the average value was increased for $2 \%$ with non-treated variant. However, there was no GE increase with seed treated with metalaxyl. Similar situation was 
with one-year old seed. Nonetheless small GE increase was achieved with non-treated seed $1 \%$, and there was no change with treated seed. Mutual influence of preparations resulted in significant increase of value of this parameter with one-yearold seed in case of non-treated variant -by $3 \%$. In case of treated variant, two-year-old seed had the highest increase in TG - 3\% as well (Table 1). Delayed seed TG leads to death of seed, particularly due to unfavourable weather conditions. Likewise, plants that germinate and spring later have big competition in plants that have sprouted in optimal term (Finch-Savage \& Leubner, 2006).

\section{Seed germination energy - sterile sand as a substrate}

Analysys of the obtained results showed that $\mathrm{L} 1$ and L2 lines, at both seed variants, had better average $\mathrm{GE}$ with relation to $\mathrm{L} 3$ and $\mathrm{L} 4$ lines. Lines L1 (OCMS-98) and L2 (HA-NS-26) had the best $\mathrm{GE}-87 \%$ at non-treated variant, while at variant treated with metalaxyl-m, line L1 (OCMS-98) had the best GE $86 \%$ (Table 2).
Seed produced in 2012 and 2011 had significantly better average value of this seed quality indicator with relation to seed produced in 2010. Seed produced in 2012 had the best GE at both variants - $92 \%$ and $90 \%$.

By analyzing average influence of biostimulators on seed GE, it can be concluded that treating seed with Slavol $S$ significantly increased seed GE by $6 \%$ at non-treated variant, i.e. $7 \%$ with variant treated with metalaxyl-m. Treatment with Bioplant Flora reduced the TG by $1 \%$, while the combination of preparations significantly reduced TG by $9 \%$, i.e., 10\%. Poštić et al. (2011) reported that faster TG of seed in the field dictates better and more even sproting of plants, rich development, greater resistance to environmental conditions, diseases and pests since more developed plants are more resistent.

Considering the OCMS-98 sunflower line, treating of seed with Slavol S and Bioplant Flora significantly improves the value of GE by an average of $6 \%$, i.e. \% with Slavol S, and for $4 \%$, i.e. $4 \%$ with Bioplant Flora. Combination of biostimulators significantly reduced the value

Table 2. Effect of biostimulators on GE on a sterile sand substrate

\begin{tabular}{|c|c|c|c|c|c|c|c|c|c|c|c|c|c|}
\hline \multirow{3}{*}{$\begin{array}{c}\text { Lines } \\
\text { A }\end{array}$} & \multirow{3}{*}{$\begin{array}{c}\text { Years } \\
\text { G }\end{array}$} & \multicolumn{6}{|c|}{ Seed non-treated } & \multicolumn{6}{|c|}{ Seed treated with metalaxyl-m } \\
\hline & & \multicolumn{4}{|c|}{ Biostimulators C } & \multirow{2}{*}{$\begin{array}{l}\text { Aver. } \\
A^{*} G\end{array}$} & \multirow{2}{*}{$\begin{array}{c}\text { Aver } \\
\text { A }\end{array}$} & \multicolumn{4}{|c|}{ Biostimulators C } & \multirow{2}{*}{$\begin{array}{l}\text { Aver. } \\
A^{*} G\end{array}$} & \multirow{2}{*}{$\begin{array}{c}\text { Aver. } \\
\text { A }\end{array}$} \\
\hline & & $S$ & B & $\mathrm{S}+\mathrm{B}$ & $\mathbf{K}$ & & & $S$ & B & $\mathrm{S}+\mathrm{B}$ & $\mathbf{K}$ & & \\
\hline \multirow{4}{*}{ L1 } & 2010 & 90 & 81 & 73 & 83 & 82 & \multirow{4}{*}{87} & 85 & 82 & 71 & 83 & \multirow{4}{*}{$\begin{array}{l}80 \\
87 \\
91\end{array}$} & \multirow{4}{*}{86} \\
\hline & 2011 & 93 & 95 & 73 & 89 & \multirow{3}{*}{$\begin{array}{l}88 \\
90\end{array}$} & & 91 & 94 & 75 & 88 & & \\
\hline & 2012 & 95 & 96 & 80 & 90 & & & 93 & 96 & 85 & 90 & & \\
\hline & $\mathrm{A}^{*} \mathrm{C}$ & 93 & 91 & 75 & 87 & & & 90 & 91 & 77 & 87 & & \\
\hline \multirow{4}{*}{ L2 } & 2010 & 84 & 79 & 81 & 78 & \multirow{4}{*}{$\begin{array}{l}81 \\
86 \\
94\end{array}$} & \multirow{4}{*}{87} & 82 & 81 & 78 & 80 & \multirow{4}{*}{$\begin{array}{l}80 \\
85 \\
91\end{array}$} & \multirow{4}{*}{85} \\
\hline & 2011 & 89 & 86 & 81 & 87 & & & 91 & 84 & 81 & 84 & & \\
\hline & 2012 & 98 & 95 & 92 & 91 & & & 92 & 91 & 91 & 90 & & \\
\hline & $\mathrm{A}^{*} \mathrm{C}$ & 90 & 87 & 85 & 85 & & & 88 & 85 & 83 & 85 & & \\
\hline \multirow{4}{*}{ L3 } & 2010 & 75 & 60 & 58 & 68 & \multirow{4}{*}{$\begin{array}{l}65 \\
85 \\
89\end{array}$} & \multirow{4}{*}{80} & 76 & 61 & 59 & 68 & \multirow{4}{*}{$\begin{array}{l}66 \\
84 \\
89\end{array}$} & \multirow{4}{*}{80} \\
\hline & 2011 & 96 & 84 & 77 & 84 & & & 97 & 83 & 74 & 81 & & \\
\hline & 2012 & 97 & 89 & 81 & 90 & & & 97 & 88 & 79 & 92 & & \\
\hline & $\mathrm{A}^{*} \mathrm{C}$ & 89 & 78 & 72 & 81 & & & 90 & 77 & 71 & 80 & & \\
\hline \multirow{4}{*}{ L4 } & 2010 & 78 & 56 & 42 & 72 & \multirow{4}{*}{$\begin{array}{l}62 \\
81 \\
92\end{array}$} & \multirow{4}{*}{78} & 79 & 54 & 37 & 70 & \multirow{4}{*}{$\begin{array}{l}60 \\
82 \\
89\end{array}$} & \multirow{4}{*}{77} \\
\hline & 2011 & 91 & 77 & 69 & 87 & & & 94 & 75 & 70 & 87 & & \\
\hline & 2012 & 96 & 95 & 89 & 87 & & & 98 & 94 & 77 & 87 & & \\
\hline & $\mathrm{A}^{*} \mathrm{C}$ & 88 & 76 & 67 & 82 & & & 90 & 74 & 61 & 81 & & \\
\hline & 2010 & 82 & 69 & 64 & 75 & Pros. & 73 & 81 & 70 & 61 & 75 & Pros. & 72 \\
\hline Aver. & 2011 & 92 & 86 & 75 & 87 & Aver. & 85 & 93 & 84 & 75 & 85 & Aver. & 84 \\
\hline & 2012 & 97 & 94 & 86 & 90 & G & 92 & 95 & 92 & 83 & 90 & G & 90 \\
\hline Ave & $\mathrm{CC}$ & 90 & 83 & 75 & 84 & Aver & $\mathrm{e} C$ & 90 & 82 & 73 & 83 & & \\
\hline
\end{tabular}

LSD

\begin{tabular}{|c|c|c|c|c|c|c|c|c|c|c|c|c|c|c|}
\hline \multirow{2}{*}{ LSD } & \multicolumn{7}{|c|}{ Seed non-treated } & \multicolumn{7}{|c|}{ Seed treated with metalaxyl } \\
\hline & A & G & C & $\mathrm{A}^{*} \mathrm{G}$ & $\mathrm{A}^{*} \mathrm{C}$ & $\mathrm{G}^{*} \mathrm{C}$ & $\mathbf{A}^{*} \mathbf{G}^{*} \mathrm{C}$ & A & G & C & $\mathrm{A}^{*} \mathrm{G}$ & $\mathrm{A}^{*} \mathrm{C}$ & $\mathrm{G}^{*} \mathrm{C}$ & $\mathrm{A}^{*} \mathrm{G}^{*} \mathrm{C}$ \\
\hline 0.05 & 4.74 & 11.27 & 2.65 & 1.50 & 1.02 & 1.53 & 19.52 & 4.88 & 11.10 & 2.76 & 1.48 & 1.08 & 1.50 & 21.07 \\
\hline 0.01 & 7.39 & 19.71 & 3.65 & 2.11 & 1.40 & 2.14 & 33.77 & 7.60 & 19.40 & 3.80 & 2.08 & 1.49 & 2.18 & 31.33 \\
\hline
\end{tabular}


of GE by an average of $12 \%$, i.e. $10 \%$ (Table 2 ). By observing the line HA-NS-26, it can be concluded that Slavol $S$ significantly improved the value of this vitality parameter by $5 \%$, i.e. $3 \%$. Bioplant Flora did not have significant influence on seed quality, and the combination of these two preparations reduced TG of treated seed by $2 \%$. The best effect of some biostimulator on sunflower seed GE was accomplished at $\mathrm{PH}$ BC2-74 line where treating the seed with Slavol $\mathrm{S}$ significantly improved GE by an average of $8 \%$, i.e. 10\%. Bioplant Flora and the combination of Slavol S + Bioplant Flora significantly reduced the value of this important seed quality indicator by an average of $3 \%$, i.e. $3 \%$ with the influence of Bioplant Flora, and for 9\%, i.e. 9\% with mutual influence of these two fertilizers. Mwale (2003) emphasized that synchronization between parent lines in the flowering period is very important in sunflower seed production in order to perform qualitative pollination of mother line. Fast and equal growth, which depends on GE, is one of the most important factors for successful sunflower seed production.

Seed of line L4 (VL-A-8) treated with Slavol S significantly improved GE by an average of $6 \%$, i.e. $9 \%$. However, Bioplant Flora treatment led to significant reduction - GE was reduced by $6 \%$, i.e. $7 \%$ on a three-year average. Taking this into consideration, but all other examined lines as well, the most negative effect was achieved by the application of combination of the two fertilizers - GE was reduced by $15 \%$, i.e. 20 with relation to control variant (Table 2).

Analyzing the influence of biostimulators on TG, depending on the seed age, where sterile sand was used as a substrate, it can be concluded that the best effect was achieved with Slavol S. With its influence, TG was significantly improved. There was an increase in the value of this parameter with three-year-old seed by an average of $7 \%$, i.e., $6 \%$, with two-year-old seed by an average of $12 \%$, i.e., $8 \%$ and with one-year-old seed by an average of $7 \%$. Bioplant Flora had positive effect on one-yearold seed by significantly improving the value of this parameter - by $4 \%$ and $2 \%$. With the increase of seed age, application of this parameter led to negative effect. TG was not significantly reduced with two-year-old seed, while it was significantly reduced with three-year-old seed - by $6 \%$, i.e., $5 \%$. Combination led to significant reduction of seed quality. TG was reduced by $4 \%$, i.e., for $7 \%$ with one-year-old seed, by $12 \%$, i.e., $10 \%$ with two-year-old seed, while with three-year-old seed the TG was reduced by $11 \%$ i.e., $14 \%$ with respect to control variant. Kolomazik et al. (2012) determined that in order for biostimulators to have desired effect, they must penetrate the plant tissue. This is of great importance, especially in field conditions where treated plants are exposed to different weather conditions.

\section{Seed germination - filter paper as a substrate}

The analysys of the obtained results showed that line L1 (OCMS-98), at both seed variants, had significantly better TG with relation to other lines. Average TG of this line with non-treated variant was $98 \%$ while with treated one it was $98 \%$.

Seed produced in 2011 and 2012 had significantly better value of this seed quality indicator with relation to seed produced in 2010 (Table 3). Seed produced in 2012 had the best TG - 99\%, i.e. $98 \%$. Effect of biostimulators on seed TG showed that treating seed with fertilizer Slavol S gave the best results on average. With relation to control variant, treatment with this biostimulator significantly increased TG, by an average of $4 \%$, i.e. $6 \%$. Treatment with Bioplant Flora, but also mutual influence of these two fertilizers led to significant improvement of TG for $2 \%$, i.e. $3 \%$ and $2 \%$, i.e. $3 \%$. Fertilizers that contain humic acids significantly positively affected seed TG which is in agreement with Türkmen et al. (2004) on tomato seed.

By observing how biostimulators affected seed TG of a particular sunflower genotype, it can be concluded that in some cases they had stimulative, and in some inhibitory effect. Treating seed with all biostimulators in line $\mathrm{L} 1$ resulted in significant increase of TG with relation to control variant. Treatment with Slavol S improved TG by $5 \%$, i.e. $5 \%$, with Bioplant Flora by 5\%, i.e. $4 \%$ and their combination by $6 \%$, i.e. $4 \%$. Given results are in concord with Paravan (2013) who emphasized that application of biostimulators which contain organic matter with macro and micro elements, if are applied in particular period of plant growth, represent high technique for optimization of nutrition and health of plants. By analyzing mother line of sunflower L2, in non-treated variant, application of Slavol $S$ and Bioplant Flora significantly increased TG by $2 \%$, i.e. $5 \%$ and by $2 \%$ i.e. $4 \%$ while its combination had inhibitory influence and significantly reduced $\mathrm{TG}$ by $3 \%$, i.e. 2\% (Table 3).

All biostimulators achieved significant increase of seed TG in L3 line with relation to control variant. The best effect was achieved by Slavol $S-$ $6 \%$, Bioplant Flora $-2 \%$, while their combination had an influence on increase of this important 
Table 3. Effect of biostimulators on TG on a filter paper substrate

\begin{tabular}{|c|c|c|c|c|c|c|c|c|c|c|c|c|c|}
\hline \multirow{3}{*}{$\begin{array}{r}\text { Lines } \\
\text { A }\end{array}$} & \multirow{3}{*}{$\begin{array}{r}\text { Years } \\
\mathrm{G}\end{array}$} & \multicolumn{6}{|c|}{ Seed non-treated } & \multicolumn{6}{|c|}{ Seed treated with metalaxyl-m } \\
\hline & & \multicolumn{4}{|c|}{ Biostimulators C } & \multirow[b]{2}{*}{$\begin{array}{l}\text { Aver. } \\
\qquad A^{*} G\end{array}$} & \multirow[b]{2}{*}{$\begin{array}{c}\text { Aver. } \\
\text { A }\end{array}$} & \multicolumn{4}{|c|}{ Biostimulators C } & \multirow[b]{2}{*}{$\begin{array}{c}\text { Aver. } \\
A^{*} G\end{array}$} & \multirow[b]{2}{*}{$\begin{array}{c}\text { Aver. } \\
\text { A }\end{array}$} \\
\hline & & $S$ & B & $\mathrm{S}+\mathrm{B}$ & $\mathbf{K}$ & & & $S$ & B & $\mathrm{S}+\mathrm{B}$ & $\mathbf{K}$ & & \\
\hline \multirow{4}{*}{ L1 } & 2010 & 97 & 97 & 99 & 91 & 96 & \multirow{4}{*}{98} & 98 & 95 & 98 & 91 & \multirow{4}{*}{$\begin{array}{l}96 \\
98 \\
99\end{array}$} & \multirow{4}{*}{98} \\
\hline & 2011 & 100 & 100 & 100 & 93 & \multirow{3}{*}{$\begin{array}{l}98 \\
99\end{array}$} & & 99 & 100 & 98 & 94 & & \\
\hline & 2012 & 100 & 100 & 100 & 97 & & & 100 & 100 & 99 & 96 & & \\
\hline & $\mathrm{A}^{*} \mathrm{C}$ & 99 & 99 & 100 & 94 & & & 99 & 98 & 98 & 94 & & \\
\hline \multirow{4}{*}{ L2 } & 2010 & 85 & 83 & 74 & 84 & 82 & \multirow{4}{*}{92} & 87 & 86 & 73 & 82 & 82 & \multirow{4}{*}{92} \\
\hline & 2011 & 98 & 98 & 93 & 95 & \multirow{3}{*}{$\begin{array}{l}96 \\
99\end{array}$} & & 98 & 97 & 96 & 92 & 96 & \\
\hline & 2012 & 100 & 100 & 99 & 97 & & & 100 & 100 & 96 & 95 & 98 & \\
\hline & $\mathrm{A}^{*} \mathrm{C}$ & 94 & 94 & 89 & 92 & & & 95 & 94 & 88 & 90 & & \\
\hline \multirow{4}{*}{ L3 } & 2010 & 88 & 85 & 82 & 80 & \multirow{4}{*}{$\begin{array}{l}84 \\
97 \\
98\end{array}$} & \multirow{4}{*}{93} & 89 & 85 & 83 & 79 & 84 & \multirow{4}{*}{93} \\
\hline & 2011 & 98 & 95 & 98 & 96 & & & 98 & 95 & 99 & 96 & 97 & \\
\hline & 2012 & 100 & 97 & 100 & 96 & & & 100 & 97 & 100 & 96 & 98 & \\
\hline & $\mathrm{A}^{*} \mathrm{C}$ & 95 & 92 & 93 & 91 & & & 96 & 92 & 94 & 90 & & \\
\hline \multirow{4}{*}{ L4 } & 2010 & 88 & 82 & 85 & 82 & \multirow{4}{*}{$\begin{array}{l}84 \\
95 \\
98\end{array}$} & \multirow{4}{*}{92} & 89 & 83 & 84 & 81 & \multirow{4}{*}{$\begin{array}{l}84 \\
95 \\
98\end{array}$} & \multirow{4}{*}{92} \\
\hline & 2011 & 99 & 92 & 96 & 91 & & & 99 & 92 & 95 & 92 & & \\
\hline & 2012 & 100 & 95 & 100 & 98 & & & 100 & 96 & 99 & 97 & & \\
\hline & $\mathrm{A}^{*} \mathrm{C}$ & 96 & 90 & 94 & 90 & & & 96 & 90 & 93 & 90 & & \\
\hline & 2010 & 90 & 87 & 85 & 84 & Pros. & 87 & 91 & 87 & 85 & 83 & Pros. & 87 \\
\hline Aver. & 2011 & 99 & 96 & 97 & 94 & Aver. & 97 & 99 & 96 & 97 & 94 & Aver. & 97 \\
\hline & 2012 & 100 & 98 & 100 & 97 & $\mathrm{G}$ & 99 & 100 & 98 & 99 & 96 & G & 98 \\
\hline Averag & & 96 & 94 & 94 & 92 & Average & & 97 & 94 & 94 & 91 & & \\
\hline
\end{tabular}

LSD

\begin{tabular}{|c|c|c|c|c|c|c|c|c|c|c|c|c|c|c|}
\hline \multirow[b]{2}{*}{ LSD } & \multicolumn{7}{|c|}{ Seed non-treated } & \multicolumn{7}{|c|}{ Seed treated with metalaxyl } \\
\hline & $\mathrm{A}$ & $\mathrm{G}$ & $\mathrm{C}$ & $\mathrm{A}^{*} \mathrm{G}$ & $\mathrm{A}^{*} \mathrm{C}$ & $\mathrm{G}^{*} \mathrm{C}$ & $\mathrm{A}^{*} \mathrm{G}^{*} \mathrm{C}$ & $\bar{A}$ & $\mathrm{G}$ & $\mathrm{C}$ & $A^{*} G$ & $\mathrm{~A}^{*} \mathrm{C}$ & $\mathrm{G}^{*} \mathrm{C}$ & $\mathrm{A}^{*} \mathrm{G}^{*} \mathrm{C}$ \\
\hline 0.05 & 3.64 & 9.23 & 3.04 & 1.22 & 0.68 & 1.15 & 18.02 & 3.59 & 9.05 & 3.41 & 1.20 & 0.66 & 1.13 & 17.37 \\
\hline 0.01 & 5.67 & 16.13 & 4.73 & 1.71 & 0.93 & 1.62 & 29.34 & 5.59 & 15.83 & 5.31 & 1.68 & 0.91 & 1.59 & 29.52 \\
\hline
\end{tabular}

indicator of seed quality for 4\%. Identical results were obtained with processed variant. By analyzing L4 sunflower line, it can be concluded that treatment with Slavol $S$ gave the best results at both variants. Treatment with this fertilizer resulted in significant increase of TG by $6 \%$, i.e. $6 \%$, while using Bioplant Flora did not lead to any changes. Combination of biostimulators $(B+S)$ resulted in significant increase of TG - by $4 \%$, i.e. 3\% (Table 3).

By observing the effect of bistimulators on seed GE, depending on its age, it can be concluded that treating the seed with Slavol $S$ prior to sowing led to significant increase in GE, regardless of the seed production year. The best influence was achieved with three-year-old seed where GE increased by an average of $6 \%$, i.e., $8 \%$, with two-year-old seed by $5 \%$, i.e., $5 \%$, while with one-year-old seed, GE increased by $3 \%$, i.e., for $4 \%$. Just like Slavol S, Bioplant Flora had significant effect on GE of old seed, but to a lesser extent. GE was significantly improved with three-year-old seed by an average of $3 \%$, i.e., for $4 \%$. GE increased by $2 \%$, i.e., for $2 \%$ with two-year-old seed, while the value of this important indicator of seed vitality with one-yearold seed increased by $1 \%$, i.e., $2 \%$.

Unlike by separate influence of preparations, where the best effect was achieved with the oldest seed, the least efficiency was achieved by mutual influence, thus there was not so significant increase in GE. Effect of biostimulators with two-year-old and one-year-old seed led to significant increase of seed quality value, by an average of $3 \%$ with regard to control variant.

\section{Seed total germination - sand as a substrate}

At both seed variants, lines L1 and L2 had better TG with relation to parent sunflower lines L3 and L4. Line L1 (OCMS-98) had the best TG $93 \%$, i.e. $93 \%$. Seed produced in 2012 and 2011 had significantly better value of this seed quality indicator with relation to three-year-old seed (Table 4). Seed produced in 2012 had the best TG $-96 \%$, i.e. $97 \%$.

By observing the effect of bistimulators on sunflower seed TG, it can be concluded that treating seed with Slavol S and Bioplant 
Table 4. Effect of biostimulators on TG on a sterile sand substrate

\begin{tabular}{|c|c|c|c|c|c|c|c|c|c|c|c|c|c|}
\hline \multirow{3}{*}{$\begin{array}{r}\text { Lines } \\
\mathbf{A}\end{array}$} & \multirow{3}{*}{$\begin{array}{c}\text { Years } \\
\text { G }\end{array}$} & \multicolumn{6}{|c|}{ Seed non-treated } & \multicolumn{6}{|c|}{ Seed treated with metalaxyl-m } \\
\hline & & \multicolumn{4}{|c|}{ Biostimulators } & \multirow{2}{*}{$\begin{array}{c}\text { Aver. } \\
\mathrm{A}^{*} \mathrm{G}\end{array}$} & \multirow{2}{*}{$\begin{array}{r}\text { Aver. } \\
\text { A }\end{array}$} & \multicolumn{4}{|c|}{ Biostimulators C } & \multirow{2}{*}{$\begin{array}{c}\text { Aver. } \\
\mathrm{A}^{*} \mathrm{G}\end{array}$} & \multirow{2}{*}{$\begin{array}{r}\text { Aver. } \\
\text { A }\end{array}$} \\
\hline & & $\mathbf{S}$ & B & $\mathrm{S}+\mathrm{B}$ & $\mathbf{K}$ & & & $\mathrm{S}$ & B & $\mathrm{S}+\mathrm{B}$ & $\mathbf{K}$ & & \\
\hline \multirow{4}{*}{ L1 } & 2010 & 93 & 92 & 79 & 91 & \multirow{4}{*}{$\begin{array}{l}89 \\
94 \\
96\end{array}$} & \multirow{4}{*}{93} & 92 & 93 & 78 & 91 & \multirow{4}{*}{$\begin{array}{l}89 \\
93 \\
97\end{array}$} & \multirow{4}{*}{93} \\
\hline & 2011 & 97 & 99 & 84 & 95 & & & 97 & 98 & 83 & 95 & & \\
\hline & 2012 & 99 & 99 & 90 & 95 & & & 100 & 99 & 91 & 96 & & \\
\hline & $\mathbf{A} * \mathbf{C}$ & 96 & 97 & 84 & 94 & & & 96 & 97 & 84 & 94 & & \\
\hline \multirow{4}{*}{$\mathbf{L} 2$} & 2010 & 90 & 91 & 83 & 87 & \multirow{4}{*}{$\begin{array}{l}88 \\
92 \\
97\end{array}$} & \multirow{4}{*}{92} & 90 & 89 & 82 & 87 & \multirow{4}{*}{$\begin{array}{l}87 \\
92 \\
96\end{array}$} & \multirow{4}{*}{92} \\
\hline & 2011 & 95 & 93 & 86 & 92 & & & 95 & 93 & 85 & 93 & & \\
\hline & 2012 & 100 & 98 & 92 & 96 & & & 99 & 97 & 91 & 96 & & \\
\hline & $\mathrm{A} * \mathrm{C}$ & 95 & 94 & 87 & 92 & & & 95 & 93 & 86 & 92 & & \\
\hline \multirow{4}{*}{$\mathbf{L} 3$} & 2010 & 79 & 77 & 67 & 76 & \multirow{4}{*}{$\begin{array}{l}75 \\
93 \\
95\end{array}$} & \multirow{4}{*}{88} & 80 & 77 & 68 & 75 & \multirow{4}{*}{$\begin{array}{l}75 \\
93 \\
97\end{array}$} & \multirow{4}{*}{88} \\
\hline & 2011 & 99 & 95 & 85 & 92 & & & 100 & 95 & 86 & 91 & & \\
\hline & 2012 & 99 & 97 & 89 & 96 & & & 100 & 99 & 90 & 97 & & \\
\hline & $\mathrm{A} * \mathrm{C}$ & 92 & 90 & 80 & 88 & & & 93 & 90 & 81 & 88 & & \\
\hline \multirow{4}{*}{ L4 } & 2010 & 83 & 78 & 67 & 78 & \multirow{4}{*}{$\begin{array}{l}77 \\
90 \\
97\end{array}$} & \multirow{4}{*}{88} & 83 & 79 & 68 & 79 & \multirow{4}{*}{$\begin{array}{l}77 \\
91 \\
97\end{array}$} & \multirow{4}{*}{88} \\
\hline & 2011 & 100 & 90 & 82 & 89 & & & 100 & 90 & 82 & 90 & & \\
\hline & 2012 & 100 & 100 & 91 & 96 & & & 100 & 100 & 92 & 96 & & \\
\hline & $\mathbf{A}^{*} \mathbf{C}$ & 94 & 89 & 80 & 88 & & & 94 & 90 & 81 & 88 & & \\
\hline \multirow{3}{*}{$\begin{array}{l}\text { Aver. } \\
\qquad \mathrm{G}^{*} \mathrm{C}\end{array}$} & 2010 & 86 & 85 & 74 & 83 & Pros. & 82 & 86 & 85 & 74 & 83 & Pros. & 82 \\
\hline & 2011 & 98 & 94 & 84 & 92 & Aver. & 92 & 98 & 94 & 84 & 92 & Aver. & 92 \\
\hline & 2012 & 100 & 99 & 91 & 96 & G & 97 & 100 & 99 & 91 & 96 & G & 97 \\
\hline Ave & ge $C$ & 95 & 93 & 83 & 90 & Aver & ge $\mathrm{C}$ & 95 & 93 & 83 & 90 & & \\
\hline
\end{tabular}

LSD

\begin{tabular}{|c|c|c|c|c|c|c|c|c|c|c|c|c|c|c|}
\hline \multirow[b]{2}{*}{ LSD } & \multicolumn{7}{|c|}{ Seed non-treated } & \multicolumn{7}{|c|}{ Seed treated with metalaxyl } \\
\hline & $\mathbf{A}$ & $\mathbf{G}$ & $\mathrm{C}$ & $A * G$ & $\mathrm{~A}^{*} \mathrm{C}$ & $\mathrm{G}^{*} \mathrm{C}$ & $\mathrm{A} * \mathrm{G} * \mathrm{C}$ & $\mathbf{A}$ & $\mathbf{G}$ & $\mathrm{C}$ & $A * G$ & $\mathrm{~A}^{*} \mathrm{C}$ & $\mathrm{G} * \mathrm{C}$ & $A * G * C$ \\
\hline 0.05 & 3.78 & 9.81 & 5.16 & 1.20 & 0.87 & 1.33 & 21.52 & 3.73 & 9.87 & 5.11 & 1.29 & 0.85 & 1.35 & 20.03 \\
\hline 0.01 & 5.88 & 17.15 & 8.03 & 1.68 & 1.20 & 1.86 & 33.02 & 5.81 & 17.25 & 7.96 & 1.80 & 1.17 & 1.89 & 33.07 \\
\hline
\end{tabular}

Flora significantly improved TG while the combination $\mathrm{S}+\mathrm{B}$ significantly reduced this value. Slavol $S$ increased TG by $5 \%$, i.e. $5 \%$, Bioplant Flora by $3 \%$, i.e. $3 \%$, while their combination has negative influence on seed vitality and significantly reduced TG by $7 \%$ at non-treated variant, i.e. $7 \%$ at variant treated with metalaxyl. Individual analysis of mother sunflower line showed that significant increase of GE with OCMS-98 line was achieved only with Slavol S and Bioplant Flora. Slavol S improved TG by $2 \%$, i.e. $2 \%$, Bioplant Flora by $3 \%$, i.e. $3 \%$, while their combination significantly reduced the GE - by $10 \%$ with both variants (Table 4 ). Biostimulators had weaker effect on line L2 while their combination affected seed TG negatively. Slavol S significantly increased the value of this important seed quality indicator by $3 \%$, i.e. 3\%. Bioplant Flora had smaller, but significant effect and treating seed with this biostimulator prior to sowing increased TG by $2 \%$, i.e. $1 \%$. Combination of the fertilizers lead to significant reduction of $\mathrm{TG}$ as high as by $5 \%$, i.e. by $6 \%$. By observing the influence of biostimulators on TG of sunflower line L3, it can be noticed that application of Slavol $S$ had the best effect on seed TG and significantly the increased the value of this parameter by $4 \%$, i.e. $5 \%$. Bioplant Flora also significantly influenced seed vitality and increased TG by $2 \%$, i.e. $2 \%$. Combination of these two fertilizers had inhibitory influence on seed quality and leads to significant reduction of TG by $8 \%$, i.e. $7 \%$ (Table 4 ).

The best effect on the increase of seed TG in line $\mathrm{L} 4$ was accomplished by treating the seed with Slavol S - 6\%, i.e. 6\%. Fertilizer Bioplant Flora achieved weaker but significant influence and it increased TG by $1 \%$, i.e. $2 \%$. Combination of biostimulators led to negative effect and seed TG with both variant was significantly reduced by an average of $8 \%$ with relation to control variant.

By analyzing the influence of biostimulators on seed GE, depending on its age, it can be concluded that individual influence of Slavol $S$ and Bioplant Flora had positive effect on GE while their combination significantly reduced the value of seed quality indicator. Slavol S significantly increased GE of three-year-old seed, by an average of $4 \%$, i.e., $4 \%$. The best effect of this preparation was achieved with two-year-old seed, where GE increased by $6 \%$, i.e., $6 \%$, while treating one-year-old seed with Slavol $S$ increased GE by $3 \%$, i.e., $3 \%$. This is in agreement with Poincelot (1993). According to him, biostimulators that contain humic acids lead 
to improvement of TG and root development. Influence of Bioplant Flora significantly increased the GE, but to a lesser extent than influence of Slavol S. Three-year-old seed increased GE by $2 \%$, i.e., $3 \%$. Average increase of GE, $2 \%$ with all variants, was accomplished with two-year-old and one-year-old seed. Treating seed with combination of these two preparations significantly reduces the GE. The biggest reduction was noticed with threeyear-old seed, by an average of $9 \%$. With two-yearold seed, GE was reduced by an average of $8 \%$, while the value was reduced by an average of 5\% with one-year-old seed (Table 4).

\section{Conclusions}

Effect of biostimulators depends on genotype, but on the age of seed as well. Choosing adequate biostimulator for a particular genotype can lead to increase of TG, which favourably influences the number of plant per unit area, and by all means the yield too. However, choosing the inadequate biostimulator or their combination can lead to the opposite effect, i.e. to certain reduction of seed quality parameters, TG and GE. Thus, choosing biostimulators must be done with great care and prior to treating the seed it is necessary to conduct trial testing in order to avoid negative consequences.

Biostimulators accomplish significantly better influence when used on filter paper than on sterile sand. Likewise, better efficiency, but not significant, was seen on seed treated with metalaxyl.

\section{References}

Crnobarac, J. (1992). Uticaj ekoloških faktora na biološka i agronomska svojstva semena i $F_{1}$ generaciju nekih genotipova suncokreta. Doctoral dissertation. University of Novi Sad, Faculty of Agriculture.

Finch-Savage, W., \& Leubner-Metzger, G. (2006). Seed dormancy and the control of germination. New Phytology, 171, 501523. Rewiew.

Food and agriculture organization of the United Nations (2013). FAOSTAT, Production, ProdSTAT, Crops. Retrieved from http://faostat.fao.org.

Fries, N. (1951). The influence of amino acids on growth and lateral root formation in cotyledon-less pea seedlings. Experientia, 7 (10), 378-379. doi:10.1007/BF02168907.

Govedarica, M., Milošević, N., Jarak, M., Đurić, S., Jelić, Z., Kuzevski, J., \& Đorđević, S. (2002). Primena biofertilizatora, biostimulatora i biopesticida u poljoprivrednoj proizvodnji. Zbornik radova, 37, 85-95.

Hadživuković, S. (1991). Statistički metodi. Novi Sad: Poljoprivredni fakultet.

ISTA (2009): International Rules for Seed Testing. International Seed Testing Association, Switzerland.

Kolomaznik, K., Pecha, J., Friebrovà, V., Janàčovà, D., \& Vašek, V. (2012). Diffusion of biostimulators into plant tissues. Heat and Mass Transfer. 48, 1505-1512.

Lua, T. H., \& Böhme, M. (2001). Influence of humic acid on the growth of tomato in hydroponic systems. Acta Horticulturae, 548, 451-458.

Miklič, V., Dušanić, N., Škorić, D., \& Joksimović, J. (2004). Proizvodnja semena suncokreta. In: M. Milošević \& M. Malešević (Eds.). Semenarstvo. (pp. 453-458). Novi Sad: Institut za ratarstvo i povrtarstvo.

Milošević, M., Ćirović, M., Mihaljev, I., \& Dokić, P. (1996). Opšte semenarstvo. (pp. 53-60). Novi Sad: Institut za ratarstvo i povrtarstvo.

Mrđa, J., Dušanić, N., Radić, V., \& Miklič, V. (2010). Effect of different substratum on treated sunflower seed germination. Journal of Agricultural Sciences, 55, 1-8.

Mwale, S., Hamusimbi, C., \& Mwansa, K. (2003). Germination, emergence and growth of sunflower (Helianthus annuus L.) in response to osmotic seed priming. Seed Sci. and Technology, 31, 199-206.

Nenadić, V., Plazinić, N., \& Anđelović, S. (2011). Uticaj ekoloških uslova na kvalitet semena soje. Zbornik naučnih radova Instituta PKB Agroekonomik, 17, 131-135.

Parađiković, N., Vinković, T., \& Radman, N. (2008). Utjecaj biostimulatora na klijavost sjemena cvjetnih vrsta. Sjemenarstvo, 25, 25-33.

Parvan, L., Dumitru, M., Sibru, C., \& Ciorianu, T. (2013). Fertilizer with humic substances. Romanian agricultural research, 30, 206-212.

Poincelot, R. (1993). The use of a commercial organic biostimulant for bedding plant production. Journal of Sustainable Agriculture, 3, 99-110.

Poštić, D., Momirović, N., Broćić, Z., Dolijanović, Ž., Trkulja, N., Dolovac, N., \& Ivanović, Ž. (2011). Ocena kvaliteta semena paradajza (Lycopersicum esculentum L.). Zbornik naučnih radova Instituta PKB Agroekonomik, 17, 131-135.

Poštić, D., Protić, R., Aleksić, G., Gavrilović, V., Živković, S., Trkulja, N., \& Ivanović, Ž., (2010). Ispitivanje kvaliteta semena ozime pšenice u periodu 2000-2005. godine. Zaštita bilja, 61, 20-24.

Šimić, B., Ćosić, J., Liović, I., Krizmanić, M., \& Poštić, J. (2008). The influence of weather conditions and economic characteristics on sunflower hybrids in macro experiments from 1997 to 2007. In: Proc. 17th Internat. Sunfower Conf., Cordoba, Spain, 261-263. 
TeKrony, D., \& Egli, D. (1991). Relationship of seed vigour to crop yield: a rewiev. Crop Science, 31, 816-822.

Tkalec, M., Vinković, T., Baličević, R., \& Parađiković, N. (2010) Uticaj biostimulatora na rast i razvoj paprike (Capsicum annu$u m$ L.). Acta agriculturaee Serbica, 15, 83-88.

Türkmen, Ö., Dursun, A., Turan, M., \& Erdinç, C. (2004). Calcium and humic acid affect seed germination, growth, and nutrient content of tomato (Lycopersicon esculentum L.). Seedlings in saline Soil Conditions. Acta Agricultuirae Scandinavica, Section B, Soil and Plant Science, 54, 168-174.
Vinković, T., Parađiković, N., Plavšić, H., Guberac, V., \& Levai, L. (2007). Maize and soybean seed vigour under influence of seed age, seed treatment and temperature in cold stress test. Cereal Research Communications, 35, 1213-1216.

Yildirim, E., Dursun, A., Guvenc, I., \& Kumlay, M. (2007). The effects of different salt, biostimulant and temperature levels on seed germination of some vegetable species. Acta Horticulturae, 579, 249-253.

Záborsky, S., Nagy, E., \& Szöke, C. (2002). Effect of seed treatment on the emergence of inbred lines in maize (Zea mays $\mathrm{L}$.). Acta Agronomica Hungarica, 50, 359-369.

\title{
Uticaj biostimulatora na energiju klijanja i klijavost semena suncokreta
}

\author{
Zlatica Miladinov • Velimir Radić • Vladimir Miklič • Jovan Crnobarac • \\ Igor Balalić • Milan Jocković • Jelena Mrđa
}

Sažetak: Cilj rada bio je da se ispita uticaj biostimulatora na parametre kvaliteta semena - energiju klijanja i klijavost, u zavisnosti od genotipa i starosti semena suncokreta. Testiranje je sprovedeno u novosadskom Institutu za ratarstvo i povrtarstvo na četiri citoplazmatski muško sterilne linije: OCMS-98, HA-NS-26, PH-BC2-74 i VL-A-8. Seme je proizvedeno u periodu 2010-2012. Testirane su dve varijante semena: tretirano metalaksilom-m i netretirano. Seme je pre setve tretirano komercijalnim preparatima Slavol S, Bioplant Flora i njihovom kombinacijom. Ispitivanje je pokazalo da dejstvo biostimulatora zavisi od genotipa, ali i od starosti semena. Odabirom adekvatnog biostimulatora za određeni genotip može se postići povećanje energije klijanja i klijavosti, što povoljno utiče na broj biljaka po jedinici površine, a samim tim i na prinos. Međutim, izborom neadekvatnog biostimulatora ili njihove kombinacije može se postići suprotan efekat od željenog, odnosno da se parametri kvaliteta semena smanje u određenoj meri.

Ključne reči: biostimulatori, energija, klijanje, seme, starost semena, suncokret 